\title{
John Priestley
}

One of the major achievements of humanism in Renaissance Italy was the development of new historical methodologies which permitted, in Italy as well as in France, analytical treatises far more sophisticated than the chronicles of the Middle Ages. It may therefore seem strange that Montaigne did not embrace the new methodologies but rather stated preference for the old ways of writing history. This is not to say that he was unaware of the work of his contemporaries, or that he did not value history, or even, as Abraham Keller has argued, that he did not understand history at all and is to be reproached for not having developed a coherent philosophy based upon a sense of relativism with respect to temporal considerations, as he had done with respect to geographical ones. ${ }^{1}$ Rather his interests lay elsewhere, and history, like all other disciplines, is subsumed to a larger, overall purpose in the Essais.

A convenient starting point for a discussion of Montaigne's views of history and historians is a late statement (added in the posthumous 1595 edition) found in 1.21, "De la force de l'imagination": "Il y en a des autheurs desquels la fin c'est dire les evenements. La mienne, si j’y sçavoye advenir, seroit dire sur ce qui peut advenir." 2 What is important in this passage is that Montaigne did not consider himself to be an historian at all (viz. someone concerned with actual events), but something quite different-a moral philosopher-and that as such, he took it as permissible to relate probable or possible "facts": actions and events consistent with human nature which might have occurred or which could occur. In so far as the Essais are concerned, then, history figures in the total fabric as just one element among many, and its role is to provide certain kinds of proof as Montaigne worked out the problems he confronted.

In what follows, three aspects of this question will be discussed: the qualities and talents of the historian as Montaigne saw them, the specific uses of historical writing, and finally, Montaigne's concept or philosophy of history. Much of what I have to say has already been dealt with by Pierre Villey in his Les livres d'bistoire moderne utilisés par Montaigne. ${ }^{3}$ However, Villey deals only with the first two of these matters and to discuss all three in the same context permits a fuller understanding of the Essais since the relationships among the three topics reflect a logic fundamental to the author's thought. The conclusions reached ar based on scattered remarks found in many of the essays. Each quotation however has been looked at in the light of when it was written (a task facilitated by the designations (a), (b), (c) to represent the 1580,1588 and 1595 editions respectively and used in all standard modern editions), to the argument of the specific essay, and to Montaigne's own intellectual development, something we must attempt to understand if his views on anything are to have any meaning.

The essential development we can trace in his thought from 1571 (when he began writing in his tower after retirement from political life) to his final marginal notes before his death can be called one of "progressive interiorization" which reaches its most complete statement in the personal humanism of the last essays. That is to say that as time went on, and as current events seemed more and more confused and sinister, Montaigne became convinced that in order to acquire sound knowledge of anything, he had in fact to abandon the study of what was external to his being-all past and present events and 
objects-and look within himself and his own experiences for substantive truths about the human condition. This interest in himself and in his experiences is reflected in the self-portrait which is the Essais. This highly personal investigation had a specific purpose which is stated several times. For example, in "Des livres" we read: "(a) Pour moy, qui ne demande qu'à devenir plus sage, non plus sçavant (c) ou eloquent ..."4 The same idea informs the whole of the essay "De l'institution des enfans" (I. 26) in which Montaigne advises how Diane de Foix should train her as yet unborn son for the life he, as a nobleman living in the second half of the sixteenth century, will lead: that of a diplomat soldier for whom knowledge without wisdom could prove to be pernicious in the kind of pursuit his nation will demand of him.

In studying himself, then, Montaigne's predominant interest is a moral one. Whatever he can learn from history or from any other source is of value only in so far as it can be applied to his own being, which represents the entire human condition, as we shall shortly see. It is in the light of this preoccupation that we must analyse the three aspects of the question of history in the Essais already mentioned.

Montaigne's concept of the historian's function is stated implicitly in the remarks from "De la force de l'imagination" quoted at the beginning of this paper: he deals with events, with what did happen. Elsewhere in the Essais he develops more completely his ideas with respect to good and bad historians.

Essentially, the historians we can most trust are those who tell us what happened; they are witnesses to events from which we are removed by time and space. Once Montaigne had made up his mind that an historian was both competent and sincere, he felt he had no choice but to take as true whatever he had to say. However, in order to make such a value judgment, certain things had to be known. In "Un traict de quelques ambassadeurs" we read: "Et, à ce propos, à la lecture des histoires, qui est le subjet de toutes gens, j'ay accoustumé de considerer qui sont les escrivains: si ce sont personnes qui ne facent autre profession que de lettres, j'en apren principalement le stile et le langage; si ce sont medecins, je les croy plus volontiers en ce qu'ils nous disent de la temperature de l'air, de la santé et complexion des Princes, des blessures et maladies..."5 The same notion of the necessity to establish a writer's credentials is repeated in a later essay, "Des livres" (both quotations are from the 1580 edition): "Que peut-on esperer d'un medecin traictant de la guerre, ou d'un escholier traictant les desseins des Princes?"6 The most complete statement about historians is to be found in a long section in this essay. ${ }^{7}$ The preceding quotation, which is in this passage, explains why, for Montaigne, the best histories are "celles qui ont esté escrites par ceux mesmes qui commandoient aux affaires, ou qui estoient participans à les conduire, (c) ou, au moins, qui ont eu la fortune d'en conduire d'autres de mesme sorte." Hence, Caesar's accounts of the Gallic Wars have more credibility than those of the professional historian writing after the fact. This is particularly true if the historian in question is a non-Roman. "Et davantage," he writes (in "Defense de Seneque et de Plutarque,") "il est bien plus raisonnable de croire en telles choses (he is attacking Dio Cassius and other moderns for their criticisms of Seneca) les historiens Romains que les Grecs et estrangers." 8

There remains the important question of the judgment an historian brings to bear in his writings. In interpreting Montaigne's remarks (from "Des livres") I am somewhat more conservative than Villey. The matter merits quoting the text at length: 
(a) J'ayme les Historiens ou fort simples ou excellens. Les simples, qui n'ont point dequoy y mesler quelque chose du leur, et qui n'y apportent que le soin et la diligence de r'amasser tout ce qui vient à leur notice, et d'enregistrer à la bonne foy toutes choses sans chois et sans triage, nous laissent le jugement entier pour la cognoissance de la verité. Tel est entre autres, pour example, le bon Froissard, qui a marché en son entreprise d'une si franche naïfveté, qu'ayant faict une faute il ne creint aucunement de la reconnoistre et corriger en l'endroit où il en a esté adverty; et qui nous represente la diversité mesme des bruits qui couroyent et les differens rapports qu'on luy faisoit. C'est la matiere de l'Histoire, nue et informe; chacun en peut faire son profit autant qu'il a d'entendement. Les biens excellens ont la suffisance de choisir ce qui est digne d'estre sçeu, peuvent trier de deux rapports celuy qui est plus vraysemblable; de la condition des Princes et de leurs humeurs, ils en concluent les conseils et leur attribuent les paroles convenables. Ils ont raison de prendre l'authorité de regler nostre creance à la leur; mais certes cela n'appartient à guieres de gens. Ceux d'entre-deux (qui est la plus commune façon), ceux là nous gastent tout; ils veulent nous mascher les morceaux; ils se donnent loy de juger, et par consequent d'incliner l'Histoire à leur fantaisie; car, dépuis que le jugement prend d'un costé, on ne se peut garder de contourner et tordre la narration à ce biais. Ils entreprenent de choisir les choses dignes d'estre sçeuës, et nous cachent souvent telle parole, telle action privée, qui nous instruiroit mieux; obmetant, pour choses incroyables, celles qu'ils n'entendent pas, et peut estre encore telle chose, pour ne la sçavoir dire en bon Latin ou François. Qu'ils estalent hardiment leur eloquence et leur discours, qu'ils jugent à leur poste; mais qu'ils nous laissent aussi dequoy juger après eux, et qu'ils n'alterent ny dispersent, par leurs racourcimens et par leurs chois, rien sur le corps de la matiere: ains, qu'ils nous la r'envoyent pure et entiere en toutes ses dimensions. ${ }^{9}$

Villey emphasizes that according to Montaigne, the best historians "jugent pour nous; ils démêlent dans l'histoire ce qui est digne d'être su, ils l'interprètent, ils nous machent le besogne et nous rendent un grand service." ${ }^{10}$ Montaigne of course does say this, but it seems to me to be quoting him out of context without adding: "mais certes cela n'appartient à guieres de gens," and that the vast majority are "ceux d'entre-deux" who are scarcely to be believed at all. It is significant that although Montaigne states a preference for two kinds of historians, he gives no examples of those who are "bien excellens." Furthermore, he uses the same language when dealing with the excellent ones and the vast majority. There is only one difference: the majority of historians merely attempt what the handful of excellent ones achieve. Stating it simply, the sceptical Montaigne tells us to accept the word of historians who are "fort simples" but to reject the mass of historical writing which is analytical or interpretive as totally untrustworthy. The historian in whom we can have most confidence, then, is the man who honestly and frankly reports in chronicle fashion what happened, even when what he records may appear absurd (as in the case of some popular beliefs). Of Tacitus he says: “C'est trèsbien dict. Qu'ils nous rendent l'histoire plus selon qu'ils reçoivent que selon qu'ils estiment." 11 It is important to note parenthetically that the long passage quoted is found in the 1580 edition, but the latter one did not appear until the enlarged second edition of 1588 . His distrust of those who interpret historical events never wavered. This is partly because of his scepticism, but partly also because if historical lessons are to replace actual experiences, their effect is dimin- 
ished if someone else includes his interpretation to stand between the reader and the recorded event. This is because of the particular benefits to be gleaned from the reading of history.

Throughout the Essais, Montaigne never ascribes to the study of history a more important purpose than that of furnishing moral lessons to be followed in his own life, in the lives of his contemporaries, and by extension, in those of all men at all times. Villey states it thus: "Donc, si Montaigne nous recommande si fort l'histoire, c'est avant tout parce que c'est une école de morale. En lisant les historiens, nous ne devons jamais perdre de vue la pratique de la vie." 12 Statements in several essays confirm this idea.

In the earlier essays, one of Montaigne's preoccupations is the problem-or fact-of death and the best way to prepare for it. The lessons of history are not to be overlooked. In the essay "Que philosopher c'est apprendre à mourir", (in a passage which appeared in the first edition of the Essais) (1. 20) he says: "et n'est rien dequoy je m'informe si volontiers, que de la mort des hommes: quelle parole, quel visage, quelle contenance ils y ont eu; ny endroit des histoires, que je remarque si attentivement."13

But historical models teach us not only how to die, or demonstrate how certain men faced death, they also give us valuable lessons for life. In I. 26 ("De l'institution des enfans"), where the author's concern is how best to prepare a nobleman for his duties in the turbulent political world of sixteenth century France, he advises, in a lengthy passage, that the young man should read history books with this purpose in mind:

En cette practique des hommes, j'entends y comprendre, et principalement, ceux qui ne vivent qu'en la memoire des livres. Il practiquera, par le moyen des histoires, ces grandes ames des meilleurs siecles. C'est un vain estude, qui veut; mais qui veut aussi, c'est un estude de fruit inestimable: (c) et le seul estude, comme dit Platon, que les Lacedemoniens eussent reservé à leur part. (a) Quel profit ne fera-il en cette part-là, à la lecture des Vies de nostre Plutarque? Mais que mon guide se souvienne où vise sa charge; et qu'il n'imprime pas tant à son disciple (c) la date de la ruine de Carthage que les meurs de Hannibal et de Scipion, my tant (a) où mourut Marcellus, que pourquoy il fut indigne de son devoir qu'il mourut là. Qu'il ne luy apprenne par tant les histoires, qu'à en juger. ${ }^{14}$

The same thoughts are expressed in the key essay, "Des livres" (II. 10), where those texts which specifically tell us something about men are preferred by Montaigne. Thus, speaking of Cicero, he states a strong predilection for the letters Ad Atticum, which he enjoys for their historical facts certainly, but "beaucoup plus pour y descouvrir ses humeurs privées. Car j'ay une singuliere curiosité, somme j'ay dit ailleurs, de connoistre l'ame et les naifs jugemens de mes autheurs." 15 The same passage contains other remarks expressing similar sentiments. In a marginal comment appearing in the 1595 edition he says, when speaking of history, that "l'homme en general, de qui je cherche la cognoissance, y paroist plus vif et plus entier qu'en nul autre lieu." The important words here are "en general," for in his later life, Montaigne was of the opinion that to know oneself was the best way to know all of mankind. The whole of the last essay, "De l'expérience" is based upon this premise. There is an initial shift from the external world (which we cannot know in any detail) to the internal world of the self (with the aid of external examples), and then a surer and more solid grasp of others, both those living in books and our contemporaries. The examples provided by history are in a sense more reliable than those our own 
daily acquaintances give us because in the passing moments of conversations and immediate observations, we are likely to see only what is superficial. This is why writers of lives such as Plutarch, are preferred: they are concerned more with what "(a) part du dedans qu'à ce qui arrive au dehors." This realization that what is apparent is not always the truth (the distinction between appearance and reality) is a seminal idea to be found from the very first edition of the Essais. The advantage books have over daily experiences is that we can meditate upon them, and re-read them. Caesar, for example, is to be studied not just for his historiography, but "pour luy mesme, tant il a de perfection et d'excellence par dessus tous les autres."16

If the experiences of others are of value to us, our own, because of their immediacy, are of even greater value. In fact, lessons are to be learned even from disasters. In the third book of the Essais, in which there are very few specific references to the role of history, he comments ("De la phisionomie") upon the ruination of his country which he sees taking place all around him and which he is powerless to stop. Nevertheless, he can say that "suis content d'estre destiné à y assister et m'en instruire."17 This statement reflects, along with others, Montaigne's rather remarkable later optimism. Even when faced with the dual threat of his own deteriorating health and the attendant suffering, and the political and social chaos from which it did not seem France would emerge without ineradicable scars, he still sought positive lessons which could help him in his particular pursuit: to glean from all of life's experiences something of intimate and immediate value.

It is clear that the lessons of history are particular incidents chosen by Montaigne for their intrinsic merits, with little regard for when or where the specific events took place. This is explained by the philosophy of history in which Montaigne believed. There is nowhere in the Essais a complete statement of this philosophy: it is rather to be found in passages from only a few assays. These remarks provide clues not just to how Montaigne viewed the history of man, but also to his general philosophy of life. The first of these passages, and in many ways the most difficult, is to be found at the very beginning of III. 2 "Du repentir", a passage of the 1588 edition which contains a paradox: that of the inconstant constat element in human history, the nature of the human condition.

Les autres forment l'homme; je le recite et en represente un particulier bien mal formé, et lequel, si j'avoy à façonner de nouveau, je ferois vrayement bien autre qu'il n'est. Mes-huy c'est fait. Or les traits de ma peinture ne fourvoyent point, quoy qu'ils se changent et diversifient. Le monde n'est qu'une branloire perenne. Toutes choses y branlent sans cesse: la terre, les rochers du Caucase, les pyramides d'Aegypte, et du branle public et du leur. La constance mesme n'est autre chose qu'un branle plus languissant. Je ne puis asseurer mon object. Il va trouble et chancelant, d'une yvresse naturelle. Je le prens en ce point, comme il est, en l'instant je m'amuse à luy. Je ne peints pas l'estre. Je peints le passage: non un passage d'aage en autre, ou, comme dict le peuple, de sept en sept ans, mais de jour en jour, de minute en minute. Il faut accomoder mon histoire à l'heure. Je pourray tantost changer, non de fortune seulement, mais aussi d'intention. C'est un contrerolle de divers et muables accidens et d'imaginations irresoluës et, quand il y eschet, contraires: soit que je sois autre moymesme, soit que je saisisse les subjects par autres circonstances et considerations. Tant y a que je me contredits bien à l'adventure, mais la vérité, comme disoit Demades, je ne la contredy point. Si mon ame pouvoit prendre pied, je ne m'essaierois pas, je me resoudrois; elle est tousjours en apprentissage et en espreuve. 
Je propose une vie basse et sans lustre, c'est tout un. On attache aussi bien toute la philosophie morale à une vie populaire et privée que à une vie de plus riche estoffe; chaque bomme porte la forme entiere de l'bumaine condition. ${ }^{18}$

The passage is long, but because it contains so many vital ideas necessary to an understanding of Montaigne's thought, it merits close attention. The crucial points are those italisized: that everything is in constant and unending change (even the ostensibly most permanent objects); that the human condition is marked by no less change-in fact the transitions are rapid and constantly occurring-and lastly, that each of us is representative of the total human condition. In the midst of such bewildering diversity, then, (and as every reader of Montaigne knows, nothing is so protean as man) there is a constant element which is man, and it is therefore possible to find truth only in the study of the individual: hence the "essai" which is Montaigne's study of himself.

In the light of this, what can we state specifically about Montaigne's notion of history in this and subsequent passages? It is characterized by two fundamental qualities: dynamism and diversity, two innate tendencies causing the degree of confusion which to Montaigne has limited our knowledge of what has gone on and is going on around us and which consequently prevents us from making any discernible progress. In the "Apologie pour Raimond Sebond", there is an early reference of the 1580 edition to our scanty knowledge of the world both past and present and the later observation (a marginal comment appearing in 1595 ) that there have been "opinions populaires et monstrueuses et des moeurs et creances sauvages"19 at all times. The new point here is the constancy of man's weakness and the clear statement that whatever progress is, it does not consist of improvement in man's conduct. In the same essay, another important idea is expressed. "Si (ainsi, in modern French) nous voyons tantost fleurir un art, une opinion, tantost une autre, par quelque influence celeste; tel siecle produire telles natures et incliner l'humain genre a tel ou tel ply." 20 Much of what happens in human affairs is the result of pure chance, just as chance determines what past events will be recorded ("De la gloire": "Nous n'avons pas la millieme partie des escrits anciens; c'est la fortune qui leur donne vie, ou plus courte, ou plus longue, selon sa faveur",21), or as Rome's greatness at a particular time was more the result of a purely fortuitous coming together of events and conditions than because of any agglomeration of human achievements ("De la vanité"). ${ }^{22}$ Therefore, historical writing is often to be taken with a grain of salt: it is necessarily incomplete and so does not provide us with truth; those who write it are men with all the weaknesses peculiar to the human condition.

A major point is expressed in "Des coches":

Nous n'allons point, nous rodons plustost, et tournoions çà et là. Nous nous promenons sur nos pas. Je crains que nostre cognoissance soit foible en tous sens, nous ne voyons gueres luin, ny guere arriere; elle embrasse peu et vit peu, courte et en estandue de temps et en estandue de matiere. ${ }^{23}$

This short passage (it is entirely of the 1588 edition) is the most important statement of Montaigne's concept of history. In fact, the essential point is contained in the quite emphatic first sentence. If Montaigne saw the history of man as basically a dynamic, continuing phenomenon, he did not see it as a progression from one point to another, with each stage adding to man's betterment and his understanding of the world, as Bodin envisaged it: he was no willing precursor of the Enlightenment's theory of progress. Nor did he 
have a view of history as a series of recurring events (the so-called cyclical view) which some may see in remarks made in the last essay, "De l'experience": "Les hommes mescognoissent la maladie naturelle de leur esprit: il ne fait que fureter et quester, et va sans cesse tournoiant, bastissant et s'empestrant en sa besogne, comme nos vers de soye, et s'y estouffe. 'Mus in pice.' "24 The circular movement suggested is really the dizzying effect the hurly-burly of existence has upon us all and is simply another way of saying that mankind, like the mouse in the pitch barrel, goes sniffing around in all directions at once, something to which for Montaigne the whole panorama of history attests. There is no plan or organization, no discernible logical progression from age to age: there is simply chaos, compounded by the fortuitous nature of events. The root cause of all this - as the short quotation above suggests-is the fact that our knowledge "soit foible en tous sens" because of the "maladie naturelle de [leur] esprit."

All these considerations inform the last essay, "De l'experience", which is the summa of Montaigne's thought, and which brings together in one long and complex definitive statement all the ideas discussed. Because we can have only the most scanty and inadequate knowledge of the world around us, both past and present, because in the process of time man has set up institutions which are far from perfect, because, finally, of the confusion and ostensible incoherence in the universe and in society, the only recourse is to study oneself for answers concerning the human condition, an intellectual viewpoint which reflects Montaigne's ultimately optimistic outlook. For all his remarks about man's inadequacies, weaknesses and follies, for the page after page of hyperbolical denunciation of the faculty of reason in the "Apologie", he does not in the end downgrade man: he was far too much a renaissance humanist for that. He had great respect for the human condition and this is why he devoted his energies to a long attempt to examine it, ending with the self-portrait which attests not just to human frailties but also to human dignity. It is optimistic too because implicit in what he says is the suggestion that if others were to follow his lead and attempt to understand their own being and lot, mankind might achieve higher levels of understanding and ultimately the human condition might perhaps improve.

It is obvious that history as a subject of investigation can claim no more special place in the Essais than any other subject: all are subsumed to the principle purpose which is an "essai" at arriving at some kind of understanding of the human condition. Montaigne was not a scholar as we understand the term, but a dilettante and a nobleman who was active in the highest administrative and political circles at a particularly troubled time in history. His writings are a highly personal collection of essays he claimed would have little appeal beyond his own time. His search was a moral one and all his sources (almost entirely the moral philosophy of antiquity and the lessons to be learned from the lives of the great) served to construct a personal morality and mode of living. His interest is in factual truth, not transcendental truth: religion was to be accepted without question and totally without the use of reason. Man vis-à-vis his God was a personal question and concerned eternity. Ther temporal problems with which Montaigne was concerned could only be solved by using what is of this world. And as we have seen, much of what is to be found in this world is of little use. No comfort can be taken from the fact that time progresses. Excellence appears for strange reasons: the ancients achieved great heights in matters of moral philosophy, but in other areas they were no better or worse than Montaigne's contemporaries. There were in his view examples of superb human achievement in his own day, but there was also the horror of civil and religious strife. Mankind, in effect, had made virtually no 
moral progress since antiquity, and it seemed the world was being plunged into the worst kind of depravity. Unlike many of the historians of his own day, Montaigne saw no linear progression in the history of man, but rather consistent chaos and disorder.

\section{York University}

\section{Notes}

1 Abraham C. Keller, "Historical and Geographical Perspective in the Essais of Montaigne,"

Modern Pbilology, vol. LIV, no. 3 (1957), 145157.

2 Montaigne, Oeuvres complètes, ed. by Albert Thibaudet and Maurice Rat (Paris, 1962), I.21, p. 104.

3 Pierre Villey, Les livres d'bistoire moderne utilisés par Montaigne, (Paris, 1908).

4 Montaigne, op. cit. II. 10, p. 393.

5 I. 17, p. 72.

6 II. 10, p. 398.

7 II. 10 , pp. $396-400$.

8 II. 32 , p. 700.

9 II. 10 , p. 397.

10 Villey, op. cit., p. 24.

11 Montaigne, op. cit., II. 10, p. 922.

12 Villey,op. cit., p. 21.

13 Montaigne, op. cit., I. 20, p. 88.

14 I. 26 , p. 155.

15 II. 10 , p. 394.

16 II. 10, p. 396.

17 III. 12, p. 1023.

18 III, 2, p. 782.

19 II. 12 , p. 556.

20 II. 12 , p. 559.

21 II. 16, pp. 611-612.

22 III. 9, p. 937.

23 III. 6, p. 885 .

24 III, 13, p. 1044. 